\title{
Boost for Antarctic research
}

\section{Sydney}

IN line with the prime minister's concern for the environment, the Australian government has greatly increased support for research in the Antarctic and on the greenhouse effect in its annual budget. One hundred and thirty-five projects, 10 per cent more than last year, will be allocated \$59.8 million for the 1989-90 year. This is an increase of almost $\$ 16$ million. About a quarter of the projects focus on research relating to the greenhouse effect, depletion of the ozone layer, research into the history of climate change and future climatic trends.

Much of the allocation will go toward a new Antarctic air-transport system to be tested over the summer months. Trials for an intercontinental Australia-Antarctica air link will involve two Royal Australian Air Force Hercules flights from Hobart in Tasmania to an ice runway at Casey station, one of three Australian permanent year-round research stations in the Antarctic. If successful, the trials may open the way for the introduction of a permanent Antarctic air-transport programme by 199091 .

At present, travel to Antarctica from Tasmania can take up to six weeks by sea. According to Rex Moncur, acting director of the Antarctic Division of the federal Department of the Environment, an air link will not harm the environment. "Unlike the French, we are not using a rock platform, but an ice runway. The 2 per cent of the land mass that is rock is the major habitat of wildlife, whereas there is little wildlife on the ice. We will, however, conduct a two-stage environmental impact

study just before the trial and a more detailed one before any full-scale air operation. An air link would mean that we could design research projects without having to consider whether we can get personnel or equipment in rapidly, and it will also encourage more senior people to do research in the Antarctic."

Funding has also been provided for the chartering of the marine research and supply ship, Aurora Australis. Since the sinking of the Nella Dan in 1987, Australia has been without a fully equipped marine research vessel. Two supply ships have been providing transport for passengers and cargo to and from the continent, but they have only limited research capabilities.

Unlike any other ship working the Antarctic, the Australis is designed to have no fuel tanks in its outer hull, making an oil-spill unlikely even in the event of an accident.

One of the first projects earmarked for the Australis will be to determine the amount of damage done by commercial trawling, particularly by Japanese boats. Other projects, both continuing and new, include investigations of the effect of increased ultraviolet radiation and carbon-dioxide levels on Antarctic and sub-Antarctic plants; research designed to limit the environmental impact of Australia's Antarctic research stations; analysis of ice core to determine the composition of the Earth's atmosphere in past ages; and, finally, studies of seasonal variations in atmospheric aerosol concentration and gas emissions from Antarctic waters

Tania Ewing

\section{HUMAN GENOME}

\section{Support for Japan's sequencers from MESC}

Tokyo

THE Science Council of Japan's Ministry of Education, Science and Culture (MESC) has decided to give a small boost to attempts to start a human genome project in Japan. But launch of a full-scale project is still a long way off.

In line with recommendations received from the Science Council earlier this month, the ministry is to provide $¥ 600$ million (about $\$ 4$ million) for a two-year preparatory study to be led by Kenichi Matsubara of Osaka University. The money, the first financial commitment to the human genome project by the ministry, will be released in September from 'emergency' funds, a source which shows that the ministry considers the project to be a matter of some urgency, says Matsubara.

The sum is comparable to that already being spent by the Science and Technology Agency to develop an automatic DNA-

\section{sequencing machine.}

A decision on how the money will be used is not expected until next month. But Matsubara hopes that some of it will go to improve repositories and computer facilities, such as the DNA data bank at the National Institute of Genetics in Mishima.

The preparatory study, which will be carried out by about 20 researchers, including computer experts and biologists, will look at three key issues: training and recruiting of research staff, dissemination of results and ethical issues of genome sequencing.

Matsubara hopes to recruit many more researchers to the project over the two-year period. But he says that some researchers are concerned that the project may drain resources from other fields and he is trying to raise money from private industry and other sources.
US opposition to milk hormone

\section{Boston}

IN response to pressure from farm organizations and environmental groups, five of the largest supermarket chains in the United States agreed last week that their house brands of dairy products would not contain milk from cows injected with the genetically engineered hormone bovine somatotropin (BST).

The boycott by 2,500 supermarkets in the United States follows heated debate in Europe (see Nature 340, 415; 10 August 1989) and comes despite US Food and Drug Administration (FDA) approval for experimental use of the peptide hormone. When BST is injected into cows once or twice a month it can increase milk production by as much as 30 per cent. More than a hundred cattle herds have tested the hormone in the last four years.

FDA has yet to license BST fully for marketing and routine use but milk and meat from experimentally treated herds can be sold for human consumption. FDA representative Bonnie Aikman says that the data upon which that decision was reached will be published early next year in a scientific journal.

The announcement by the food companies came in response to a letter, challenging the companies to set out their positions, from the Foundation on Economic Trends, the group led by Jeremy Rifkin.

Paul Bernish, public affairs director at the Kroger Company, the largest US supermarket chain, affirms his company's belief in the role of the FDA to test new products to insure a safe food supply. But Bernish says "prudence" dictated his company's decision. "Until the government reaches a final decision", he says, "we simply would prefer not to have such products in our milk supply." Earlier this summer, the Vermont legislature called for a moratorium on the commercial use of bovine growth hormones pending a congressional investigation of its impact on farmers and consumers. Other major dairy states have introduced legislation to ban hormone-treated milk.

Rifkin's group and some $\mathbf{4 0}$ other farm and environmental organizations last week petitioned the FDA to stop all sale of BSTtreated milk until final licensing is approved. They asked the FDA to reveal the location of test herds and to undertake a long-term study that will take into account the health of the nation's cattle, the possibility of long-term effects on humans and the economic impact on dairy farmers.

Aikman says that the FDA has yet to review the petition formally. But she stresses that the agency has no right to examine the economic effects of BST use. "We're here simply to rule on the issue of the product's safety."

Seth Shulman 